\title{
Antiseptic effect of natural teat dip containing lactic acid against mastitis-causing Escherichia coli
}

\author{
Rinrada Chotigarpa ${ }^{1}$, Kannika Na Lampang ${ }^{1}$, Surachai Pikulkaew ${ }^{2,4}$, Siriporn Okonogi ${ }^{3,4}$, Pirote Silman ${ }^{5}$, \\ and Raktham Mektrirat ${ }^{1,4}$
}

\begin{abstract}
1. Department of Veterinary Biosciences and Public Health, Faculty of Veterinary Medicine, Chiang Mai University, Chiang Mai 50100, Thailand; 2. Department of Food Animal Clinic, Faculty of Veterinary Medicine, Chiang Mai University, Chiang Mai 50100, Thailand; 3. Department of Pharmaceutical Sciences, Faculty of Pharmacy, Chiang Mai University, Chiang Mai 50200, Thailand; 4. Research Center of Pharmaceutical Nanotechnology, Chiang Mai University, Chiang Mai 50200, Thailand; 5. Faculty of Animal Science and Technology, Maejo University, Chiang Mai 50290, Thailand. Corresponding author: Raktham Mektrirat, e-mail: raktham.m@cmu.ac.th

Co-authors: RC: rchotigarpa@gmail.com, KNL: kna_lampang@hotmail.com, SP: surapikulkaew@gmail.com, SO: okng2000@gmail.com, PS: pirote@mju.ac.th

Received: 01-09-2018, Accepted: 04-02-2019, Published online: 15-03-2019
\end{abstract}

doi: 10.14202/vetworld.2019.397-401 How to cite this article: Chotigarpa R, Na Lampang K, Pikulkaew S, Okonogi S, Silman P, Mektrirat R (2019) Antiseptic effect of natural teat dip containing lactic acid against mastitis-causing Escherichia coli, Veterinary World, 12(3): 397-401.

\begin{abstract}
Aim: This study aimed to estimate the enumeration of total bacteria and coliform on teat skin from dairy cows and evaluate the efficacy of the natural rice gel containing 5\% v/v lactic acid (NGL) against Escherichia coli standard and field strains isolated from bovine teat skin.

Materials and Methods: A total of 100 bacterial teat skin samples ( 25 cows) were collected from dairy cows in smallholder farm. The cows were housed in freestall barns. The colonization of total bacteria and E. coli on teat skin was measured by $3 \mathrm{M}$ Petrifilm method. The minimum inhibitory concentration (MIC) and the minimum bactericidal concentration (MBC) of lactic acid were evaluated for reference strain of $E$. coli ATCC 25922 and two field strains of $E$. coli. The natural teat sanitizer was formulated using $5 \%$ NGL with modified rice gel. In vitro antiseptic efficacy of 5\% NGL was determined by time-kill kinetic assay. E. coli morphology after exposure with 5\% NGL was examined under a scanning electron microscope (SEM).

Results: The total bacteria and coliform counts from bovine teat skin were $2.11 \times 10^{4}$ and $1.54 \times 10^{1}$ colony-forming units $/ \mathrm{ml}$, respectively. The MIC and MBC of lactic acid on the tested bacteria were $0.5 \% \mathrm{v} / \mathrm{v}$. The natural teat dip was successfully prepared with minimum change in consistency after 1 year of storage at $4{ }^{\circ} \mathrm{C}$. The reduction rate of $5 \% \mathrm{NGL}$ on $E$. coli ATCC 25922 and field strain showed $32.77 \%$ and $27.58 \%$, respectively. An appearance under SEM of non-viable $E$. coli after being incubated with 5\% NGL clearly showed atypical form and rough surface cell membrane.
\end{abstract}

Conclusion: The rice gel containing $5 \% \mathrm{v} / \mathrm{v}$ lactic acid is a promising preparation as a natural teat antiseptic for reducing bacteria on teat skin. It was shown to be effective against $E$. coli causing bovine mastitis in dairy cows.

Keywords: antiseptic, Escherichia coli, lactic acid, teat skin.

\section{Introduction}

In the dairy industry, bovine mastitis is a critical problem of economic loss, milk loss and affects milk components. The prevalence of clinical and subclinical mastitis is $16-48 \%$ and $29-79 \%$, respectively [1-5]. Although the prevalence of clinical mastitis is lower than subclinical, it can result in severe milk loss and a high risk of cow culling. Escherichia coli are the etiological agents often isolated from clinical cases in India and China [6,7]. It is normally found in environment and gastrointestinal tract of humans and animals [8]. The common sources of exposure to Gram-negative bacteria in dairy farm include manure, contaminated bedding, water, soil, and feedstuffs.

Copyright: Chotigarpa, et al. Open Access. This article is distributed under the terms of the Creative Commons Attribution 4.0 International License (http://creativecommons.org/licenses/ by/4.0/), which permits unrestricted use, distribution, and reproduction in any medium, provided you give appropriate credit to the original author(s) and the source, provide a link to the Creative Commons license, and indicate if changes were made. The Creative Commons Public Domain Dedication waiver (http:// creativecommons.org/publicdomain/zero/1.0/) applies to the data made available in this article, unless otherwise stated.
It is the most frequent foodborne pathogen associated with milk or dairy products [9]. Poor milking practices are associated with the presence of extended-spectrum $\beta$-lactamase $E$. coli resulting in a high risk of intramammary infection and greater usage of antibiotics with the possibility of developing antibiotic resistance [10].

It is known that teat disinfection pre- and post-milking is an important tool to reduce the possibility of mastitis. Pre-milking teat disinfection will probably reduce the number of environmental pathogens, while post-milking teat disinfection is effective against contagious mastitis pathogens [11]. Pre-milking teat disinfection is not popularly used in Thailand. Hence, the prevalence of environmental mastitis pathogen is still high $[12,13]$. The prior study concluded that applying the pre-milking teat dipping showed a significant reduction in the number of bacteria on teat skin and new cases of mastitis caused by coliforms and environmental Streptococcus spp. [14,15].

2-hydroxypropanoic acid or lactic acid products have been shown to have antibacterial activities against 
Gram-positive and Gram-negative bacteria [16]. These ingredients are used in food and cosmetics as preservatives and also have low toxicity. From the previous report, lactic acid is less sensitive to skin irritation [17]. Many commercial teat antiseptic products have various active ingredients including iodine, hydrogen peroxide, chlorine, and chlorhexidine. Some may cause skin irritation and bacterial resistance [18]. Therefore, preparations of natural products are attractive.

The objectives of this research were to explore the number of total bacteria and coliforms on teat skin from smallholder dairy farm in Chiang Mai Province, Thailand. The antibacterial activities of 5\% natural gel lactic acid (NGL) against $E$. coli were investigated by time-kill kinetic assay. The preparation of NGL affected bacterial cell structure was also observed using scanning electron microscopy (SEM).

\section{Materials and Methods \\ Ethical approval}

The study was approved by the Animal Ethics Committee of the Faculty of Veterinary Medicine, Chiang Mai University, Chiang Mai, Thailand (Approval No. S37/2559).

\section{Animal and study area}

The study was conducted in a smallholder farm in Chiang Mai Province, Thailand, subregion of San Kamphaeng. The global positioning system of this subregion coordinates of $18^{\circ} 44^{\prime} 43^{\prime \prime} \mathrm{N} 99^{\circ} 7^{\prime} 13^{\prime \prime} \mathrm{E} .25$ Holstein Friesian cows were housed in freestall barn dairy farms and milked twice a day. Cows with good udder health were required for this study.

\section{Collection of teat skin samples}

A total of 100 teat skin samples (1 swab/teat of 25 cows) were collected from healthy dairy cows on July 2017-August 2017. Teat skin samples were collected after washing udder with clean water and dried before the milking process using a sterile cotton swab with phosphate-buffered saline (PBS) [19]. All samples were kept at $5^{\circ} \mathrm{C}$ and transported to the laboratory within $4 \mathrm{~h}$ for total bacteria and coliform counting.

\section{Petrifilm method for counting bacteria}

For the 3M Petrifilm method, the samples were diluted by 10 -fold dilution and $1 \mathrm{ml}$ inoculated on $3 \mathrm{M}$ Petrifilm rapid aerobic count plate and 3M Petrifilm coliform count plate for counting total bacteria and coliform, respectively. The Petrifilms were incubated at $37^{\circ} \mathrm{C}$ for $24 \mathrm{~h}$. After incubation, the number of bacterial colonies was counted with the guideline of $3 \mathrm{M}$ Petrifilm interpretation. Pink colonies were enumerated as total bacteria, while red and blue colonies with gas were counted as coliform. The limitation of $3 \mathrm{M}$ Petrifilm rapid aerobic count plate and coliform count plate is 300 and 150 colonies, respectively. If the bacteria are too many to count, the average number of bacteria can be made by counting in one square $\left(1 \mathrm{~cm}^{2}\right)$ and multiply it by 20 to get the number of total bacteria per plate[20].
Minimum inhibitory concentration (MIC) and minimum bactericidal concentration (MBC) determination

The bacterial strain of standard E. coli ATCC 25922 and the field isolates of E. coli were provided by the Faculty of Veterinary Medicine, Chiang Mai University, Thailand. An in vitro broth microdilution test was carried out to determine the MIC and MBC of lactic acid against standard E. coli ATCC 25922, and the field strains consisted of two unrelated isolates of E. coli. The bacteria cells were cultured in tryptic soy agar (Merck, Germany) plates containing 5\% sheep blood, following the National Committee for Clinical Laboratory Standards recommendation. The bacterial colonies from the agar were inoculated into test tube containing Mueller-Hinton broth (Merck, Germany), and the turbidity was adjusted to $0.5 \mathrm{McF}$ arland standard before use. Lactic acid was diluted into various concentrations of $10,5,1,0.5$, and $0.1 \% \mathrm{v} / \mathrm{v}$ in sterile distilled water in test tubes. A sterile 96 -well plate containing equal volumes of bacterial suspension and various concentrations of lactic acid was incubated at $37^{\circ} \mathrm{C}$ for $24 \mathrm{~h}$. Plates were observed for the absence or presence of turbidity. The minimum concentration of the lactic acid showing no turbidity was recorded as MIC value. The MBC value was determined by the drop plate technique on Mueller-Hinton agar (Merck, Germany) from the clear wells. The plates were incubated at $37^{\circ} \mathrm{C}$ overnight. The lowest lactic acid concentration that could completely inhibit bacterial growth is the MBC value. The MIC and MBC assays of each strain were run in duplicate.

\section{Preparation and characterization of natural gel containing lactic acid}

The nano preparation containing $5 \% \mathrm{v} / \mathrm{v}$ lactic acid was obtained from the Research Center of Pharmaceutical Nanotechnology, Chiang Mai University, Thailand. The chemical modification method of milled rice grains was performed based on the method previously described by Okonogi et al. [21] and Chotigarpa et al. [22]. Briefly, the modified rice powder was used for gel base preparation and viscosity building agent. Polysorbate 80 was used for preparing an aqueous solution of lactic acid. Then, purified water was added to adjust the final concentration of lactic acid to $5 \% \mathrm{v} / \mathrm{v}$. The mixture was gently stirred and then subjected to a high shear mixing device (Ultra-Turrax T25) at high-speed stirring of $5000 \mathrm{rpm}$ for $1 \mathrm{~min}$. The preparation was prepared under sterile condition and examined for contaminated bacteria. After freshly prepared and after 1 year storage at $4^{\circ} \mathrm{C}$, the preparation was observed with physical appearances, air bubbles, color, viscosity, and $\mathrm{pH}$. The $\mathrm{pH}$ was measured using a $\mathrm{pH}$ meter (Mettler Toledo, Greifensee, Switzerland).

\section{The time-kill kinetic assay}

An in vitro modified time-kill analysis was performed to find out the killing time of standard and two field isolates of $E$. coli. The bacterial suspension was 
adjusted to $0.5 \mathrm{McF}$ arland standards. An exact amount of $0.8 \mathrm{ml}$ of $5 \% \mathrm{NGL}$ and $0.1 \mathrm{ml}$ of bovine fetal serum was added into $0.1 \mathrm{ml}$ of each bacterial suspension. The samples were 10-fold serial diluted in PBS. The mixture samples were taken at time intervals of $30 \mathrm{~s}$ and $1,5,15,30$, and $60 \mathrm{~min}$ and inoculated aseptically into approximately $20 \mathrm{ml}$ of plate count agar (Merck, Germany) by pour plate technique at $37^{\circ} \mathrm{C}$ for $24 \mathrm{~h}$. Then, viable bacteria were counted. The procedure was performed in duplicate (two independent experiments) and a graph of the log colony-forming units $(\mathrm{CFU}) / \mathrm{ml}$ and time were plotted.

\section{Detection of bacterial morphology by SEM}

E. coli ATCC 25922 in normal saline solution (NSS) was incubated with $5 \%$ lactic acid at $37^{\circ} \mathrm{C}$ for $8 \mathrm{~h}$, while the viable bacteria in NSS without lactic acid were used as a culture control. The treated cell was fixed using $2.5 \%$ glutaraldehyde in phosphate buffer ( $\mathrm{pH} 7.4$ ) at $4^{\circ} \mathrm{C}$ for $24 \mathrm{~h}$. The specimen was dehydrated with graded ethanol and sputter coated with gold particles before examining the cell morphological appearance under SEM (JEOL JSM 5410LV, Tokyo, Japan).

\section{Statistical analysis}

All tested bacteria were normalized to CFU and then $\log 10$ transformed before analysis. The data were analyzed using one-way analysis of variance; significant differences were assumed if probabilities $<0.05$. Statistical analysis was performed with $\mathrm{R}$ statistical software (Rstudio, Boston, MA, USA).

\section{Results and Discussion}

\section{Number of total bacteria and coliform count on teat skin}

This study was performed during 2 months in a smallholder farm in Chiang Mai Province, Thailand. The results indicated that the number of total bacteria and coliform count on teat skin showed $2.11 \times 10^{4}$ and $1.54 \times 10^{1} \mathrm{CFU} / \mathrm{ml}$, respectively. A higher number of total bacteria and coliform count were $>2.50 \times 10^{4}$ and $>5.10 \times 10^{3} \mathrm{CFU} / \mathrm{ml}$, respectively, were reported from a previous study [23]. The differences in the sample area, environmental condition, and teat sanitation are possibly the causes for this variation [24]. The bacterial colonization on teat skin is an important source for intramammary infection [25]. Good sanitation practices can reduce the number of bacteria on teat skin and improve the milk quality, especially the pre-milking and post-milking teat dip [26,27].

\section{The MIC and the MBC determination}

Broth microdilution methods have been used in the determination of MIC and MBC values. The MIC and MBC values of E. coli ATCC 25922 and $E$. coli field strains toward lactic acid were $0.5 \%$. The MIC and $\mathrm{MBC}$ against all $E$. coli was $0.5 \%$ v/v. Lactic acid MBC to $\mathrm{MIC}$ ratios of E.coli was 1 . This value $<4$ was indicated as bactericidal activity [28]. The previous results showed that the lactic acid inhibited the growth of other
Gram-negative bacteria such as Shigella sp., Salmonella Enteritidis, and Listeria monocytogenes at 0.5\% [29,30]. The other prior study reported that MIC and MBC of lactic acid against Gram-negative bacteria were $\geq 0.125 \%$ and $\geq 0.25 \%$, respectively [31]. The difference between MIC and MBC was depended on bacteria strain tested and the concentration of lactic acid [32].

\section{Characterization of modified rice gel containing lactic acid preparation}

The rice gel containing 5\% lactic acid was successfully prepared. The formulation composed of lactic acid, rice gel, sodium chloride, and water. The property of this preparation was homogeneous, slightly air bubble, easy flow, and clear of color (Table-1). After 1 year that storage at $4^{\circ} \mathrm{C}$, the $\mathrm{pH}$ and color of natural gel preparation were change to 2.65 and pale yellow, respectively. Topical gel is easily passed through skin, convenient to apply and more selectively to a specific site. An adhesive property is important for increasing time at the epithelium surface. The dosage form is suitable for applying in antiseptic teat dip. In addition, the topical formulation added the moisture for hydrating skin with their emollient properties [33].

\section{The time-kill kinetic assay}

Time-kill analysis was performed to evaluate the killing time of $E$. coli ATCC 25922 and $E$. coli field strain. The killing effect of 5\% NGL was shown in Figure-1. The result demonstrated log reductions with $E$. coli ATCC 25922 and $E$. coli field strain of 3 and 2 $\log \mathrm{CFU} / \mathrm{ml}(32.77 \%$ and $27.58 \%$ ) after $60 \mathrm{~min}$ exposure time to $5 \%$ NGL, respectively. Figure- 1 shows a graph of the linear equation, with the slope of $E$. coli ATCC 25922 which had the most negative slope $(\mathrm{k}=-0.0378)$. The results indicated that the 5\% NGL has antimicrobial ability against Gram-negative bacteria causing bovine mastitis. However, a low number of coliform were observed on teat skin $\left(1.54 \times 10^{1}\right.$ $\mathrm{CFU} / \mathrm{ml}$ ). The efficiency of $5 \% \mathrm{NGL}$ is able to against $E$. coli on teat skin bacteria. From a previous study, lactic acid has been reported to reduce the population of $E$. coli $[34,35]$. The incomplete killing rate may be related to the duration of exposure time.

\section{SEM of bacterial morphology}

An appearance under SEM of viable E. coli in NSS without lactic acid as culture control is shown

Table-1: Characterization of a natural gel containing 5\% lactic acid.

\begin{tabular}{|c|c|c|}
\hline \multirow[t]{2}{*}{ Property } & \multicolumn{2}{|l|}{ 5\% NGL } \\
\hline & $\begin{array}{l}\text { Freshly } \\
\text { prepared }\end{array}$ & $\begin{array}{l}\text { After } 1 \text { year of storage } \\
\text { at } 4^{\circ} \mathrm{C}\end{array}$ \\
\hline Appearance & Homogeneous & Homogeneous \\
\hline Flow & Easy & Easy \\
\hline Air bubble & Slightly & None \\
\hline Color & Clear & Pale yellow \\
\hline $\mathrm{pH}$ & 2.54 & 2.65 \\
\hline
\end{tabular}

NGL: Natural gel lactic acid 


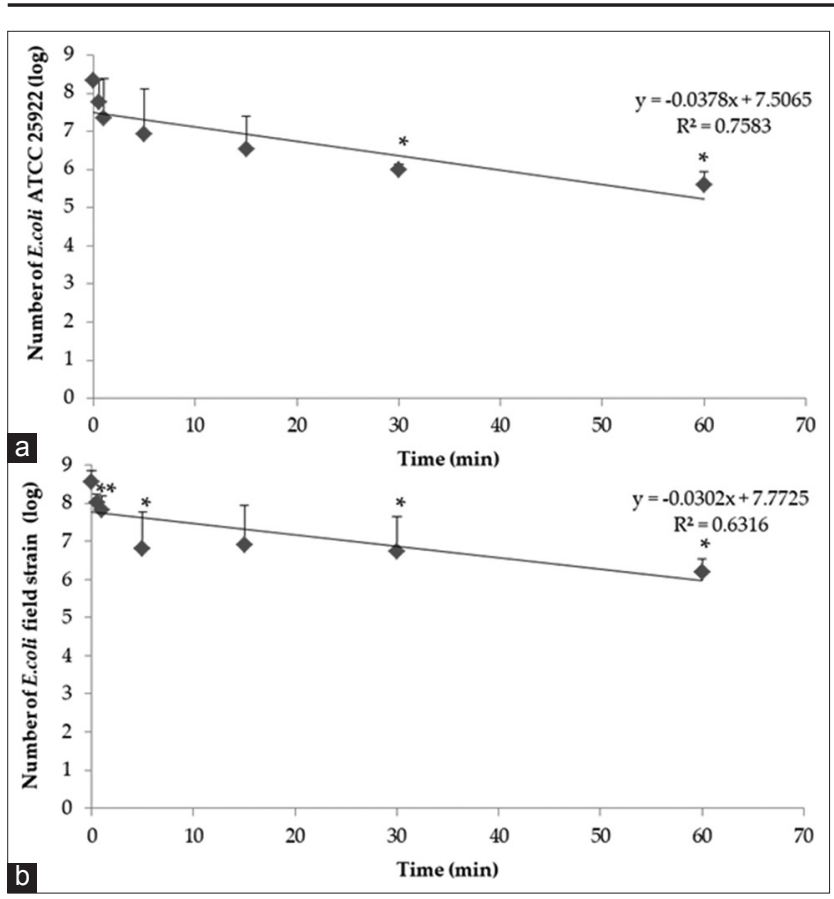

Figure-1: The killing rate of $5 \%$ natural gel lactic acid against (a) Escherichia coli ATCC 25922 and (b) E. coli field strain. Vertical bars represent the means \pm standard deviation. The line shown in the graph of the linear equation. Asterisk $(*)$ means significant differences in bacterial count at $p \leq 0.05$.
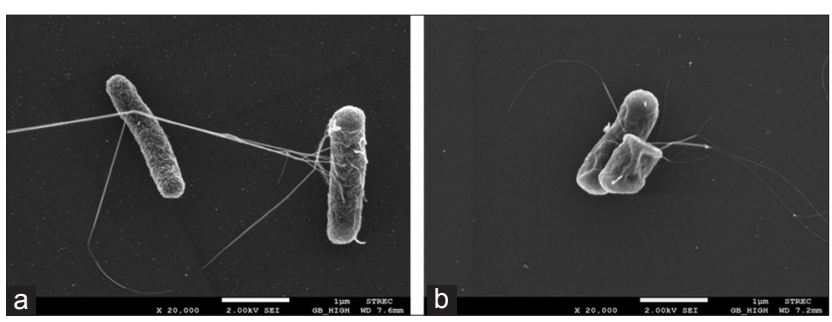

Figure-2: Scanning electron micrographs of Escherichia coli after incubation at $37^{\circ} \mathrm{C}$ for $8 \mathrm{~h}$ : (a) Viable cells $(20,000 \times)$ in normal saline solution without lactic acid; (b) non-viable cells $(20,000 \times)$ with $1 \% \mathrm{v} / \mathrm{v}$ lactic acid.

in Figure-2a. The untreated cells demonstrated typical rod shape with round end and smooth cell surfaces. The non-viable $E$. coli incubated with $1 \% \mathrm{v} / \mathrm{v}$ of lactic acid is shown in Figure-2b. After incubation with a lethal concentration of lactic acid, E. coli underwent significant morphological changes from rod shape to atypical form and rough surface cell membrane. Most of the studies about the mechanism of antibacterial lactic acid on Gram-negative bacteria focused on their effects on cellular membranes $[16,36]$. The flagella of E. coli are driven by the proton-motive force. From the previous study, the effect of weak acid on rotational speed of $E$. coli motors with intracellular $\mathrm{pH}$ was investigated [37]. When the external $\mathrm{pH}$ set at 5.0, the motor stopped completely. In this study, the $\mathrm{pH}$ of $5 \%$ NGL formulation was approximately 2.54 . The impairment of flagella of E. coli is also found to be related to acidic $\mathrm{pH}$. At acidic $\mathrm{pH}$, the expression level of the flagellin-encoding gene was decreased as compared to neutral $\mathrm{pH}$ [38].

\section{Conclusion}

The results of the present study show that the rice gel containing $5 \% \mathrm{v} / \mathrm{v}$ of lactic acid possesses antibacterial activity against $E$. coli. Our results demonstrate that the MIC and MBC of lactic acid for E. coli were $0.5 \%$. The natural gel preparation did not change during storage at $4^{\circ} \mathrm{C}$ over a period of 1 year. The product formulation reduced the rate of $E$. coli, which means that it can play an important role in preventing new intramammary infection. It can be an alternative choice due to safe, biodegradable, and restrictions on the use of antibiotics.

\section{Authors' Contributions}

SO prepared the natural rice gel. RM designed the model and the computational framework. $\mathrm{RC}$ and RM performed the laboratory investigation. RC and KNL analyzed the data. SP and PS supported material equipment and teat skin collection. $\mathrm{RC}$ and $\mathrm{RM}$ drafted the manuscript. All authors read and approved the final manuscript.

\section{Acknowledgments}

The authors are grateful for the financial support of the Agriculture Research Development Agency, Thailand (Foundation Number: CRP 5905010750).

\section{Competing Interests}

The authors declare that they have no competing interests.

\section{Publisher's Note}

Veterinary World remains neutral with regard to jurisdictional claims in published institutional affiliation.

\section{References}

1. Islam, M.A., Islam, M.Z., Islam, M.A., Rahman, M.S. and Islam, M.T. (2011) Prevalence of subclinical mastitis in dairy cows in selected areas of Bangladesh. Bangladesh. J. Vet. Med., 9(1): 73-78.

2. Plozza, K., Lievaart, J.J., Potts, G. and Barkema, H.W. (2011) Subclinical mastitis and associated risk factors on dairy farms in New South Wales. Aust. Vet. J., 89(1-2): 41-46.

3. Sharma, N., Rho, G.J., Hong, Y.H., Kang, T.Y., Lee, H.K., Hur, T.Y. and Jeong, D.K. (2012) Bovine mastitis: An Asian perspective. Asian J. Anim. Vet. Adv., 7(6): 2012.

4. Bunch, K.J., Heneghan, D.J.S., Hibbitt, K.G. and Rowllands, G.J. (1984) Genetic influences in clinical mastitis and its relationship with milk yield, season and stage of lactation. Livest. Prod. Sci., 11(1): 91-104.

5. Bartlett, P.C., Agger, J.F., Houe, H., Lawson, L.G. (2001) Incidence of clinical mastitis in Danish dairy cattle and screening for non-reporting in a passively collected national surveillance system. Prev. Vet. Med., 48(2): 73-83.

6. Yang, F., Zhang, S.D., Shang, X.F., Wang, X.R., Wang, L., Yanh, Z.T., Li, H.S. (2018) Prevalence and characteristics of extended spectrum $\beta$-lactamase-producing Escherichia coli from bovine mastitis cases in China. J. Integr. Agric., 17(6): 1246-1251.

7. Bhat, A.M., Soodan, J.S., Singh, R., Dhobi, I.A., Hussain, T., Dar, M.Y. and Mir, M. (2017) Incidence of bovine clinical mastitis in Jammu region and antibiogram of isolated pathogens. Vet. World, 10(8): 984-989. 
8. Navaneethan, R., Saravanan, S., Suresh, P., Ponnuswamy, K.K. and Palanivel, K.M. (2017) Prevalence of clinical mastitis due to E. coli in bovines. Int. J. Curr. Microbiol. Appl. Sci., 6(10): 405-409.

9. Sancak, Y.C., Sancak, H., Isleyici, O. and Durmaz, H. (2015) Presence of Escherichia coli O157 and O157: H7 in raw milk and van herby cheese. Bull. Vet. Inst. Pulawy, 59(4): 511-514.

10. Oliver, S.P. and Murinda, S.E. (2012) Antimicrobial resistance of mastitis pathogens. Vet. Clin. North Am. Food Anim. Pract., 28(2): 165-185.

11. Nickerson, S.C. (2001) Choosing the Best Teat Dip for Mastitis Control and Milk Quality. Proceedings NMCPDPW Milk Quality Conference. p43-54.

12. Boonyayatra, S. and Chaisri, W. (2004) Incidence and prevalence of subclinical mastitis in smallholder dairy farms of Chiang Mai Province, Thailand. Chiang Mai Vet. J., 1(2): 25-30.

13. Ajariyakhajorn, K., Samngamnim, S., Boonserm, T., Inchaisri, C., Thirapatsakun, T. and Farnsworth R.J. (2003) Mastitis in Small Dairy Holders of Nakhonpathom Province, Thailand. The $11^{\text {th }}$ International Symposium of the World Association of Veterinary Laboratory Diagnosticians and OIE Seminar on Biotechnology.

14. Suriyasathaporn, W. and Chupia, V. (2011) Reduction in numbers of bacteria after pre-milking teat dipping in milking dairy cows. CMU. J. Nat. Sci., 10(2): 301-306.

15. Gleeson, D., O'Brien, B., Flynn, J., O' Callaghan, E. and Galli, F. (2009) Effect of pre-milking teat preparation procedures on the microbial count on teats prior to cluster application. Ir. Vet. J., 62(7): 461-467.

16. Boomsma, B., Bikker, E., Lansdaal, E. and Stuut, P. (2015) L-lactic acid a safe antimicrobial for home and personal care formulations. Sofw J., 10(141): 2-5.

17. Alsaheb, R.A.A., Aladdin1, A., Othman, N.Z., Malek, R.A., Leng, O.M., Aziz, R. and Enshasy, H.A.E. (2015) Lactic acid applications in pharmaceutical and cosmeceutical industries. J. Chem. Pharm. Res., 7(10: 729-735.

18. Sadakane, K. and Ichinose T. (2015) Effect of the hand antiseptic agents benzalkonium chloride, povidone-iodine, ethanol, and chlorhexidine gluconate on atopic dermatitis in NC/Nga mice. Int. J. Med. Sci., 12(2): 116-125.

19. Rowbotham, R.F. and Ruegg, P.L. (2016) Bacterial counts on teat skin and in new sand, recycled sand, and recycled manure solids used as bedding in freestalls. J. Dairy Sci., 99(8): 6594-6608.

20. 3M Corporation. (2017) Aerobic Count Plate Interpretation Guide. 3M Corporation, St. Paul.

21. Okonogi, S., Kaewpinta, A., Yotsawimonwat, S. and Khongkhunthian, S. (2015) Preparation and characterization of lidocaine rice gel for oral application. Drug Discov. Ther., 9(6): 397-403.

22. Chotigarpa, R., Na Lampang, K., Pikulkaew, S., Okonogi, S., Ajariyakhajorn, K. and Mektrirat, R. (2018) Inhibitory effects and killing kinetics of lactic acid rice gel against pathogenic bacteria causing bovine mastitis. Sci. Pharm., 86(3): 1-10.

23. Baumberger, C., Guarín, J.F. and Ruegg, P.L. (2016) Effect of 2 different premilking teat sanitation routines on reduction of bacterial counts on teat skin of cows on commercial dairy farms. J. Dairy Sci., 99(4): 1-15.
24. Mbuk, E.U., Kwaga, J.K.P., Bale, J.O.O., Boro, L.A. and Umoh, J.U. (2016) Coliform organisms associated with milk of cows with mastitis and their sensitivity to commonly available antibiotics in Kaduna State, Nigeria. $J$. Vet. Med. Anim. Health., 8(12): 228-236.

25. Hassan, R., Kudi, C.A., Chiezey, N.P., Rekwot, P.I., Egbodo, B.E., Samuel, F.U., Maikaji, F.S. and Bello, T.K. (2016) Mastitis causing pathogens within the environment and teats of milking cows in Zaria, Kaduna state. J. Anim. Prod. Res., 28(1): 8-13.

26. Kučević, D., Plavšić, M., Trivunović, S., Radinović, M. and Kučević, D.S. (2013) Effect of post-milking teat dipping on hygienic quality of cow's milk. Biotechnol. Anim. Husbandry, 29(4): 665-673.

27. Gleeson, D., Flynn, J. and O' Brien, B. (2018) Effect of pre-milking teat disinfection on new mastitis infection rates of dairy cows. Ir Vet J., 71(11): 11.

28. Haas, W., Pillar, C.M., Hesje, C.K., Sanfilippo, C.M. and Morris, T.W. (2010) Bactericidal activity of besifloxacin against staphylococci, Streptococcus pneumoniae and Haemophilus influenza. J. Antimicrob. Chemother., 65(7): 1441-1447.

29. Wang, C., Chang, T., Yang, H., and Cui, M. (2015) Antibacterial mechanism of lactic acid on physiological and morphological properties of Salmonella Enteritidis, Escherichia coli and Listeria monocytogenes. Food Control, 47(1): 31-236.

30. In, Y.W., Kim, J.J., Kim, H.J. and Oh, S.W. (2013) Antimicrobial activities of acetic acid, citric acid and lactic acid against Shigella species. J. Food. Saf., 33(1): 79-85.

31. Nikolić, S.S., Dimić, G., Mojović, L., Pejin, J., Vuković, A.D. and Tanackov, S.K. (2016) Antimicrobial activity of lactic acid against pathogen and spoilage microorganisms. J. Food Process. Preserv., 40(5): 990-998.

32. Sobhy, H.M., Moghazy, G.M.E. A'al, M.H.A., Ibrahim, H.E. and Hamouda, M.S. (2017) Using lactic acid as an antimicrobial against Pseudomonas aeroginosa and validation of its test method by LC-MS/MS. Int. J. Adv. Res., 5(11): 111-119.

33. Verma, A., Singh, S., Kaur, R. and Jain, U.K. (2013) Topical gels as drug delivery systems: A review. Int. J. Pharm. Sci. Rev. Res., 23(2): 374-382.

34. Hussain, G., Rahman, A., Hussain, T., Uddin, S. and Ali T. (2015) Citric and lactic acid on the growth inhibition of $E$. coli and Salmonella Typhimurium on beef during storage. Sarhad J. Agric., 31(3): 183-190.

35. Raftari, M., Jalilian, F.A., Abdulamir, A.S., Son, R., Sekawi, Z. and Fatimah, A.B. (2009) Effect of organic acids on Escherichia coli O157: $\mathrm{H} 7$ and Staphylococcus aureus contaminated meat. Open Microbiol. J., 3(1): 121-127.

36. Alakomi, H.L., Skyttä, E., Saarela, M., Mattila-Sandholm, T., Latva-Kala, K. and Helander, I.M. (2000) Lactic acid permeabilizes gram-negative bacteria by disrupting the outer membrane. Appl. Environ. Microbiol., 66(5): 2001-2005.

37. Minamino, T., Imae, Y., Oosawa, F., Kobayashi, Y., and Oosawa, K. (2002) Effect of intracellular $\mathrm{pH}$ on rotational speed of bacterial flagellar motors. J. Bacteriol., 185(4): 1190-1194.

38. Maurer, L.M., Yohannes, E., Bondurant, S.S., Radmacher, M., and Slonczewski, J.L. (2005) pH regulates genes for flagellar motility, catabolism, and oxidative stress in Escherichia coli K-12. J. Bacteriol., 187(1): 304-319. 